\title{
FAKTOR-FAKTOR YANG BERHUBUNGAN DENGAN KEADAAN SANITASI RUMAH DI DESA SANUR KAUH KOTA DENPASAR
}

\author{
Ni Kadek Vany Arsini dan I Wayan Sudiadnyana \\ Poltekkes Denpasar Jurusan Kesehatan Lingkungan
}

\begin{abstract}
Housing is a basic human need and is also a determinant of public health. Unhealty houses because low of physical and spiritual healt. It makes desease the productive power of human. There are some problems of enviromental health economy, education, knowledge and attitude. The objectives of this study is to know the factors releated to the state of house sanitation in sanur kauh depasar village south of 2018. The method was used this study is analitic observational by cross sectional approach The subject of this study were 95 family head in sanur kauh village. This study used chi-square experiment. The faktor shaved that there were relation with the state of house sanitation education ( $p$-value 0,035), knowledge ( $p$-value 0,036) and behavior of health employee ( $p$-value 0,019) there were no signification relation beetween income and attitude of family head in the state at house sanitation in this study.
\end{abstract}

Keywords: factors, sanitation, house

\section{Pendahuluan}

Rumah sehat merupakan sarana untuk mencapai derajat kesehatan yang optimal, salah satunya ditentukan oleh ketersedian sarana sanitasi perumahan. Undang-undang Nomor 36 tahun 2009 tentang Kesehatan menegaskan bahwa upaya kesehatan lingkungan ditujukan untuk mewujudkan kualitas lingkungan yang sehat melalui upaya penyehatan lingkungan yang mencakup lingkungan pemukiman, tempat kerja, tempat rekreasi, serta tempat dan fasilitas umum(1).

Berdasarkan laporan Puskesmas tahun II Denpasar Selatan tahun 2017, Desa Sanur Kauh merupakan salah satu kawasan lingkungan pemukiman kumuh. Hal ini disebabkan karena penduduk di wilayah tersebut sebagian besar merupakan penduduk pendatang, sehingga masyarakatnya kurang memperhatikan keadaan sanitasi perumahan (2).

Tujuan dari penelitian ini adalah untuk mengetahui faktor-faktor yang berhubungan dengan keadaan sanitasi rumah di Desa Sanur Kauh Denpasar Selatan Tahun 2018. Manfaat dari penelitian ini adalah untuk menambah wawasan keilmuan dalam bidang sanitasi pemukiman dan sebagai bahan masukan dalam kegiatan penyuluhan untuk meningkatkan keadaan sanitasi rumah.

Metode

Jenis penelitian ini termasuk penelitian observasional, dengan menggunakan rancangan penelitian cross sectional yaitu menganalisa antara variabel bebas berupa pendapatan, pendidikan, pengetahuan, sikap dan perilaku petugas kesehatan dengan variabel terikat yaitu keadaan sanitasi rumah. Responden dalam penelitian ini adalah kepala keluarga yang ada di Desa Sanur Kauh yang terpilih sebagai sampel penelitian yaitu sebanyak 95 kepala keluarga ditentukan menggunakan rumus penentuan sampel (3). Teknik sampling dalam penelitian ini adalah simple rendom sampling (4). Pengumpulan data mengunakan kuesioner berupa pertanyaan tertulis yang harus dijawab oleh reponden. Data yang terkumpul dianalisis menggunakan analisis bivariat dengan uji Chi Square $\left(\mathrm{X}^{2}\right)$. Untuk mengetahui besarnya hubungan antar kedua variabel tersebut dilakukan perhitungan CoefficientContingensi(CC).

\section{Hasil dan Pembahasan}

\section{A. Pendapatan}

Berdasarkan hasil pengisian kuesioner yang dilakukan oleh kepala keluarga di Desa Sanur Kauh diperoleh 
hasil pendapatan kepala keluarga yang bertempat tinggal di Desa Sanur Kauh kauh rata- rata memiliki pendapatan kurang dari Rp. 2.363.000 sebanyak 55 orang $(57,9 \%)$.

\section{B. Pendidikan}

Berdasarkan hasil pengisian kuesioner yang dilakukan oleh kepala keluarga di Desa Sanur Kauh diperoleh hasil bahwa pendidikan kepala keluarga yang bertempat tinggal di Desa Sanur Kauh dominan berpendidikan menengah berjumlah 52 $(54,7 \%)$.

\section{Pengetahuan}

Berdasarkan hasil pengisian kuesioner yang dilakukan oleh kepala keluarga di Desa Sanur Kauh diperoleh hasil pengetahuan kepala keluarga di Desa Sanur Kauh Kauh

Perilaku petugas kesehatan mengenai keadaan sanitasi rumah di Desa Sanur Kauh Kauh Denpasar Selatan sebanyak 51 orang $(53,7 \%)$ mengatakan tidak mendukung.

\section{F.Keadaan sanitasi rumah}

Keadaan sanitasi rumah dalam penelitian ini mengunakan lembar observasi rumah sehat yang diatur dalam Kepmenkes

RI No.829/Menkes/SK/VII/1999 tentang persyaratan kesehatan perumahan (5). Berdasarkan tabel diatas, menunjukkan bahwa keadaan sanitasi rumah di Desa Sanur Kauh Kauh yang memenuhi syarat berjumlah $22(23,2 \%)$ dan tidak memenuhi syarat berjumlah $73(76,8 \%)$. Keadaan ini berbeda dengan hasil penelitian Sadono di Perumahan Pakis Tirtosari Surabaya mendapatkan bahwa $82 \%$ rumah termasuk dalam katagori baik/memenuhi syarat kesehatan (6).

Berdasarkan data tabel di atas menunjukkan bahwa pada variabel pendapatan responden yang memiliki keadaan sanitasi yang tidak memenuhi persayaratan paling banyak dengan pendapatan rendah sebanyak 38 orang. memiliki pengetahuan tinggi berjumlah 75 orang $(78,9 \%)$.

\section{Sikap}

Berdasarkan hasil pengisian kuesioner yang dilakukan oleh kepala keluarga di Desa Sanur Kauh diperoleh hasil pengetahuan kepala keluarga bertempat tinggal di Desa Sanur Kauh sebagian besar memiliki sikap mendukung sebanyak 94 orang (98,9\%). Hasil yang diperoleh setelah melakukan wawancara dengan kepala keluarga, kepala keluarga paling banyak memiliki mendukung sebanyak 94 orang $(98,9 \%)$ namun dalam pengaplikasianya masih banyak terdapat rumah yang tidak memenuhi persyaratan.

\section{E. Perilaku petugas kesehatan}

\section{G. Faktor - faktor yang berhubungan dengan keadaan sanitasi rumah}

Hasil analisis hubungan faktorfaktor yang berhubungan dengan keadaan sanitasi rumah disajikan pada tabel berikut:

\section{Tabel 7}

Faktor - faktor yang berhubungan dengan keadaan sanitasi rumah di D esa Sanur Kauh Kecamatan Denpasar Selatan Tahun 2018

\begin{tabular}{clcc} 
Variabel & Kategori & P & CC \\
\hline Pendapatan & $\begin{array}{l}\text { Rendah } \\
\text { Tinggi }\end{array}$ &, 064 &, 211 \\
\hline Pendidikan & $\begin{array}{l}\text { Dasar } \\
\text { Menengah } \\
\text { Tinggi }\end{array}$ &, 035 &, 275 \\
\hline
\end{tabular}

Setalah dilakukan analisis menggunakan uji Chi-Square di peroleh $\rho$-value 0,064 $>0,05$ sehingga Ha di terima yang berarti tidak ada hubungan signifikan antara pendapatan kepala keluarga dengan keadaan sanitasi rumah di Desa Sanur Kauh 
dengan memperoleh nilai Coefficient Contingency (CC) 0,211 yang artinya tingkat hubungan pendapatan dengan keadaan sanitasi yaitu memiliki hubungan yang rendah.

Pada variabel pendidikan menunjukkan bahwa responden yang memiliki keadaan sanitasi rumah yang tidak memenuhi syarat berjumlah 73 orang yang dominan mereka dengan Pendidikan menengah sebanyak 43 orang dan responden yang memiliki keadaan sanitasi rumah yang memenuhi persyaratan yaitu mereka yang berpendidikan tinggi sebanyak 11 orang. Setelah melakukan analisis menggunakan uji chi-square diperoleh $\rho$-value $0,035<0,05$ sehingga Ho ditolak yang berarti ada hubungan antara pendidikan dengan keadaan sanitasi rumah. Nilai Coefficient Contingency (CC) mendapatkan hasil 0,257 yang artinya tingkat hubungan pendidikan dengan keadaan sanitasi rumah yaitu memiliki hubungan yang rendah.

Adapun pada variabel pengetahuan menunjukkan bahwa responden yang memiliki keadaan sanitasi rumah yang memenuhi persyaratan dengan pengetahuan tinggi sebanyak 21 orang. Setelah dianalisis secara bivariate menggunakan uji statistik Chi Square. Hasil menunjukkan bahwa nilai p-value $<0,05$ ini artinya Ho ditolak yang artinya ada hubungan antara pengetahuan kepala keluarga dengan keadaan sanitasi rumah. Nilai Coefficient Contingency (CC) mendapatkan hasil 0,217 yang artinya ada hubungan namun masih dikatagorikan rendah.

Dari variabel sikap menunjukkan bahwa responden yang memiliki keadaan sanitasi rumah memenuhi syarat berjumlah

\section{Simpulan}

Pendapatan kepala keluarga yang bertempat tinggal di Desa Sanur Kauh memiliki pendapatan tinggi sebanyak 40 orang $(42,1 \%)$ dan pendapatan rendah sebanyak 55 orang $(57,9 \%)$. Pendidikan kepala keluarga memiliki pendidikan dasar sebanyak 16 orang $(16,8 \%)$, pendidikan
22 orang dengan sikap mendukung dan Responden yang memiliki keadaan sanitasi rumah yang tidak memenuhi syarat berjumlah 73 orang dengan proporsi responden dengan sikap tidak mendukung berjumlah satu orang, sikap mendukung berjumlah 72 orang. Setelah dianalisis secara bivariate menggunakan uji statistik Chi Square. Hasil ini menunjukkan bahwa nilai 1,000>0,05 ini artinya $\mathrm{Ha}$ diterima yang artinya tidak ada hubungan antara sikap kepala keluarga dengan keadaan sanitasi rumah dengan nilai Coefficient Contingency (CC) sebesar 0,057 yang artinya hubungan sikap kepala keluarga dengan keadaan sanitasi rumah yaitu sangat rendah.

Berdasarkan variabel perilaku petugas kesehatan menunjukkan bahwa responden yang memiliki keadaan sanitasi rumah memenuhi syarat berjumlah 22 orang dengan proporsi Perilaku petugas kesehatan yang tidak mendukung berjumlah 7 orang dan dengan Perilaku mendukung berjumlah 15 orang. Responden yang memiliki keadaan sanitasi rumah yang tidak memenuhi syarat berjumlah 73 orang dengan proporsi responden perilaku petugas kesehatan yang tidak mendukung berjumlah 44 orang dan dengan perilaku mendukung berjumlah 29 orang. Setelah dilakukan analisis menggunakan uji Chi-Square di peroleh $\rho$ -value $0,019<0,05$ sehingga Ho di tolak yang berarti ada hubungan antara perilaku petugas kesehatan dengan keadaan sanitasi rumah. Nilai Coefficient Contingency (CC) mendapatkan hasil 0,234 yang artinya ada hubungan bersignifikan antara perilaku petugas kesehatan dengan keadaan sanitasi rumah namun masih dalam kategori rendah menengah sebanyak 52 orang $(54,7 \%)$ dan sebanyak 27 orang $(28,7 \%)$ memiliki pendidikan tinggi. Pengetahuan kepala keluarga memiliki pengetahuan sedang sebanyak 20 orang $(21,1 \%)$ dan 75 orang (78,9\%) memiliki pengetahuan tinggi. Sikap kepala keluarga memiliki sikap tidak mendukung sebanyak satu orang $(1,1 \%)$ dan memiliki sikap mendukung sebanyak 
94 orang $(98,9 \%)$. Perilaku petugas kesehatan mengenai keadaan sanitasi rumah sebanyak 51 orang $(53,7 \%)$ tidak mendukung dan 44 orang (46,3\%) memiliki sikap mendukung. Keadaan sanitasi rumah yang memenuhi syarat berjumlah 22 $(23,2 \%)$ dan tidak memenuhi syarat berjumlah $73(76,8 \%)$.

Faktor-faktor yang berhubungan dengan keadaan sanitasi rumah di Desa Sanur Kauh yaitu pendidikan, pengetahuan dan perilaku petugas kesehatan sedangkan faktor-faktor yang tidak berhubungan yaitu pendapatan dan sikap kepala keluarga.

\section{Saran}

Kepada puskesmas atau petugas kesehatan di sarankan lebih banyak melaksanakan kegiatan penyuluhan untuk meningkatkan pengetahuan dan perilaku masyarakat terkait sanitasi rumah. Kepada masyarakat Desa Sanur Kauh disarankan dapat ikut berpartisipasi dalam kegiatan penyehatan perumahan secara swadaya.

\section{Daftar Pustaka}

1. Depkes-RI. Undang Undang No 36 Tahun 2009 tentang Kesehatan. Jakarta; 2009.

2. Dinkes-Kota-Denpasar. Laporan Puskesmas II Denpasar Selatan. Denpasar; 2016.

3. Notoatmodjo S. Metode Penelitian Kesehatan. Jakarta; 2010.

4. Sugiyono. Metode Penelitian Kuantitatif. Bandung: Alfabeta; 2013.

5. Kemenkes-RI. Persyaratan Kesehatan Perumahan. Jakarta; 1999.

6. Sadono DN. Jurnal Keperawatan dan
Kebidanan. J Keperawatan dan Kebidanan [Internet]. 2017;62-71. Available from: https://jurnalonline.lppmdianhusada.ac. id/index.php/jkk/article/view/105/80, 